\title{
Flight of the frigate bird: Ocean Island, phosphate mining and Project Banaba
}

\author{
Mandy Treagus \\ University of Adelaide
}

This article outlines the environmental disaster that was phosphate mining on Banaba - or Ocean Island, as it was known to outsiders. The article tracks the tactics used by what became the BPC (British Phosphate Commissioners) in extracting phosphate from the island, resulting in the removal of 90 per cent of its soil and simultaneously alienating Banabans from their land, livelihoods and culture. This process took place over 80 years, finally ending in 1981. In the course of this extraction, Banabans were removed from what was fast becoming an uninhabitable environment in 1945, when they began life on the Fijian island of Rabi. This article reflects on the ongoing legacy of bitterness and grief experienced by Banabans, together with their attempts at obtaining restitution from the Company and the governments it represented. In this context, the art installation Project Banaba $(2017 ; 2019)$ by Katerina Teaiwa is considered as a response to these histories. The article concludes with an examination of the literature that considers the removal of Banabans as a test case for climate-induced migration, noting that the singularity of the Banaban experience is not likely to be repeated, while also acknowledging the ongoing legacy of loss and grief for Banabans.

Keywords: Banaba, phosphate mining, climate-induced migration, Katerina Teaiwa, contemporary Pacific art, Pacific

\section{INTRODUCTION}

The National Library of Australia has a unique collection of photographs taken on the central Pacific island of Banaba around 1906 by Lilian Arundel, the daughter of John $\mathrm{T}$ Arundel, who obtained the original concessions to access copra and phosphate in the Gilbert and Ellice Islands. ${ }^{1}$ To see these images is to observe a people and an environment at a crucial moment. Though the environment, and the culture linked to it, are still mostly intact in this moment, the faces caught in the camera, especially those of Ewekia 'the octopus catcher' (Figure 1) and 'Queen' Nei Teienemakin (Figure 2), show both despair and defiance.

Dancing remains a significant part of Banaban culture, and one image (Figure 3) shows locals dancing before members of the phosphate company and their families. While land and sea look relatively undamaged in several images, another (Figure 4) shows workers painstakingly digging phosphate out from around the coral pinnacles

1. Arundel's guano mining company joined with Henderson and Macfarlane of Auckland 'to form the Pacific Islands Company with Lord Stanmore (formerly, as Sir Arthur Gordon, Governor of Fiji and High Commissioner for the Western Pacific) as chairman', Barrie Macdonald, Cinderellas of the Empire: Towards a History of Kiribati and Tuvalu (Australian National University Press, Canberra 1982), 94. 
104 Journal of Human Rights and the Environment, Vol. 12 No. 1

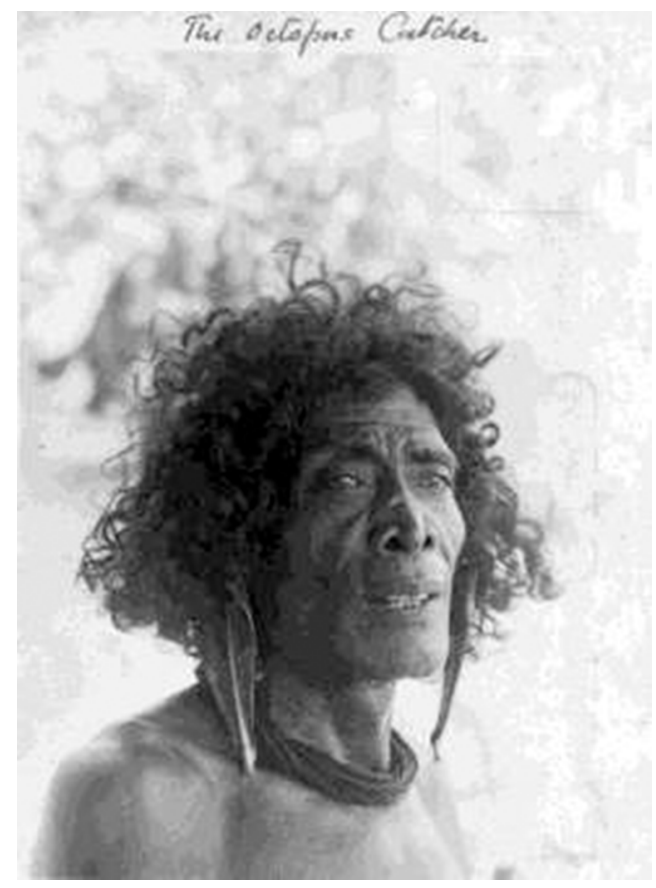

Figure 1 'Ewekia, known as the octopus catcher, Banaba, Kiribati', PAColl-6044-11, Lilian Arundel, ca. 1906, Papers of John T Arundel, National Library of Australia, MS 5410, Envelope of loose photographs, unnumbered file - Box 16

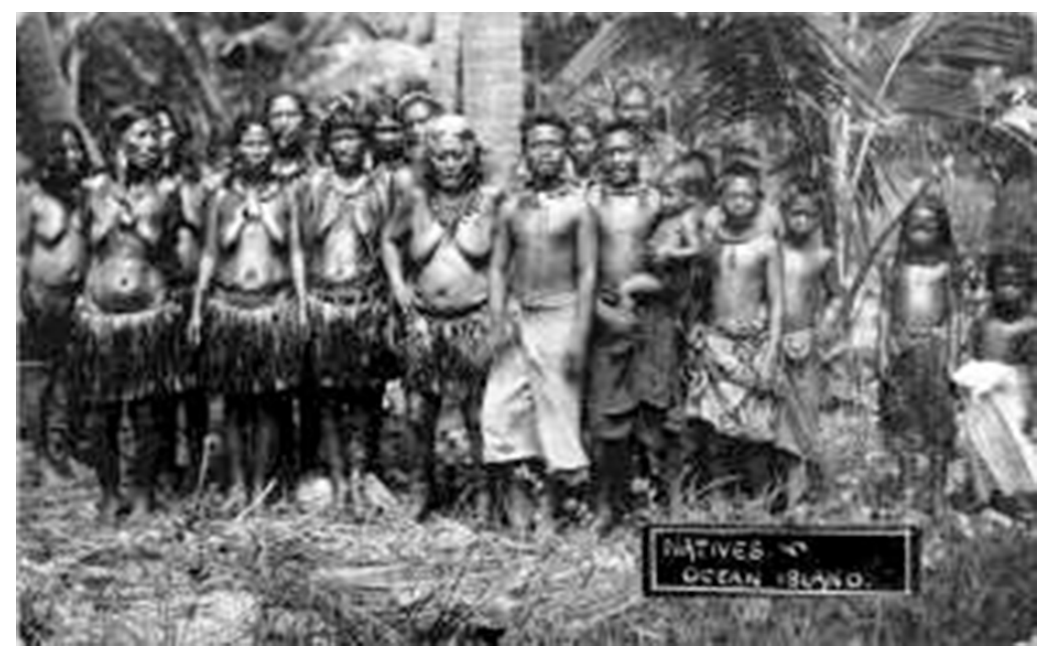

Figure 2 'Queen Tenia'makui [sic] and a group of Banaba Islanders, at Banaba, Kiribati', PAColl-6044-07, Lilian Arundel, ca. 1906, Papers of John T Arundel, National Library of Australia, MS 5410, Envelope of loose photographs, unnumbered file - Box 16 


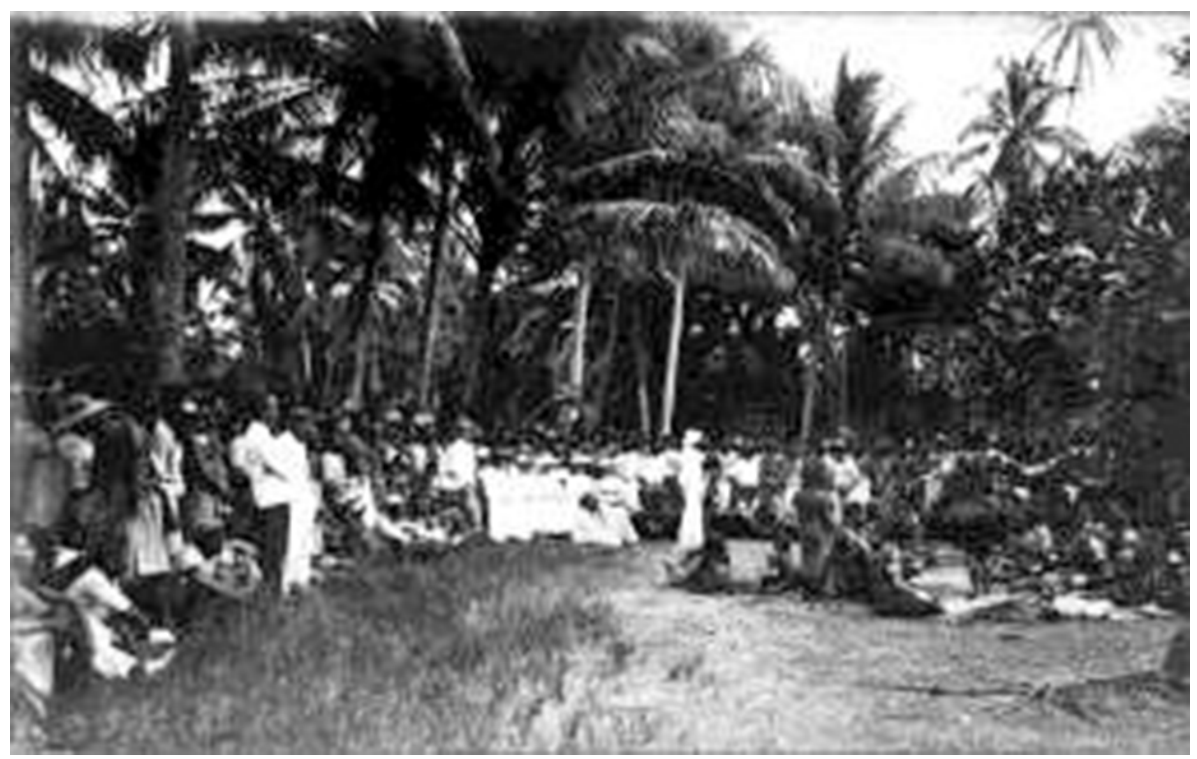

Figure 3 'Banaba Islanders performing a dance in front of visitors, at Banaba, Kiribati', PAColl-6044-05, Lilian Arundel, ca. 1906, Papers of John T Arundel, National Library of Australia, MS 5410, Envelope of loose photographs, unnumbered file - Box 16

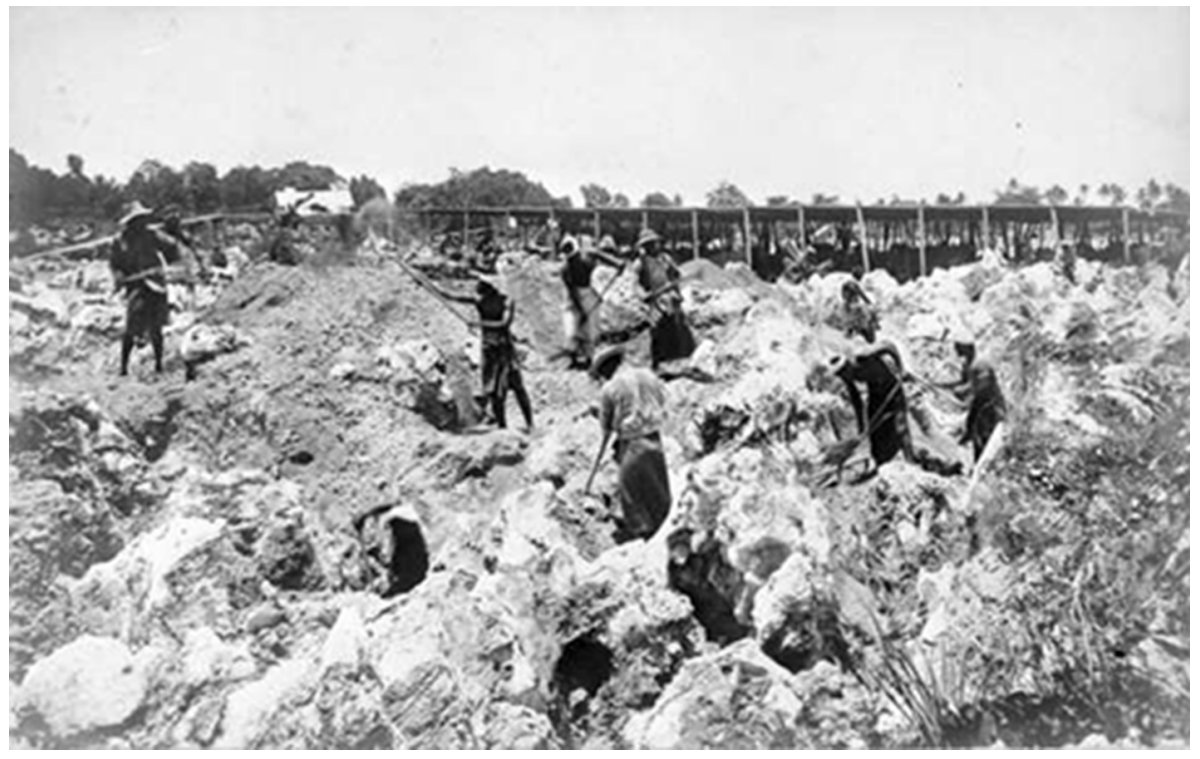

Figure 4 'Workers digging for phosphate, Banaba, Kiribati', PAColl-6044-01, Lilian Arundel, ca. 1906, Papers of John T Arundel, National Library of Australia, MS 5410, Envelope of loose photographs, unnumbered file - Box 16 
that underlay the soil of the island. The emergence of these pinnacles as the soil is taken away signals the end of much life on the island; they now dominate the landscape.

The images catch a tipping point in a process that eventually resulted in the loss of 90 per cent of the island's soil and the removal of Banaban inhabitants to Rabi in Fiji in 1945 to allow mining to continue unabated. Banaba was known as Ocean Island to outsiders throughout the late nineteenth and most of the twentieth century, named for the vessel Ocean, which was the first European craft to arrive at its shores in $1804 .^{2}$ The story of Banaba is a tale of environmental destruction and human displacement that enacts in microcosm many of the current conditions on the planet, especially in Oceania.

\section{TRADITIONAL LIFE ON BANABA}

By most measures, life on Banaba could be harsh and resources were limited. Its distance from other islands meant that very few plants, animals or birds were found there. Unlike neighbouring Nauru, the Banabans had no pigs, ${ }^{3}$ though by the time mining began, they had dogs. Perhaps because of this paucity of animal life, the frigate bird assumed great importance in Banaban life.

Eitei, frigate birds, were caught and tamed in an elaborate process undertaken only by men. Bringing down a frigate bird on the wing without hurting it required great skill. Keeping a tethered frigate bird while it was becoming tame took several weeks and required a continual supply of small fish that had to be caught. ${ }^{4}$ One practice, which involved great ceremony on both sides, was when a village ran out of tamed birds and requested some from another village. The birds were carried ceremonially, the men carrying and accompanying them oiled and garlanded with flowers. Speeches and feasting followed their arrival and the attachment of the birds to their new perches. These birds were also tamed on Nauru, and flew between the islands, originally conveying fish hooks - and with literacy, written notes: Arthur Mahaffy was told that 'a frigate bird will take a message from Ocean Island to Nauru in from four to six hours, the distance being 180 miles'. ${ }^{5}$ Depending on the source, catching and taming frigate birds has been variously described as a 'game', ${ }^{6}$ a 'cult', ${ }^{7}$ or in a more critical tone, a 'pagan tradition'. ${ }^{8}$ Having initially referred to the process as a game, Karoro Tekenimatang goes on to admit that 'actually it was more than just a game'. ${ }^{9}$ The fact that the birds were taboo to women, as were the terraces where they were caught and kept, ${ }^{10}$ suggests deeper meanings. Tamed frigate birds could not be maintained when the islanders were eventually forced to leave their island, but as Tekenimatang notes,

2. Arthur Mahaffy, 'Ocean Island', Blackwood's Magazine, November 1910, 1.

3. Albert F Ellis, Ocean Island and Nauru: Their Story (Angus and Robertson, Sydney 1936), 92.

4. Karoro Tekenimatang, 'Te Kabwane Eitei - Catching a Frigate Bird', in Jennifer Shennan and Makin Corrie Tekenimatang (eds), One and a Half Pacific Islands: Stories the Banaban People Tell of Themselves (Wellington, Victoria University Press 2005), 49-52, 50.

5. Mahaffy (n 2), 11.

6. Tekenimatang (n 4), 49.

7. Mahaffy (n 2), 9.

8. Pearl Binder, Treasure Islands: The Trials of the Ocean Islanders (Blond and Briggs, London 1977), 130.

9. Tekenimatang (n 4), 50.

10. HS and HE Maude, The Book of Banaba: From the Maude and Grimble Papers; and Published Works (University of the South Pacific, Suva 1994), 66. 
'the movements of our dancing were originally inspired by frigate birds flying, so in a sense they are with us still'. ${ }^{11}$

Rather than having a typical western Pacific diet built around root crops like taro, yams, plantains and sweet potato, Banabans relied mostly on the sea and on tree crops. ${ }^{12}$ Pandanus was the most common of these. Grown as a textile and otherwise considered to be famine food by many Pacific islanders, Banabans processed the fruit to make it edible, drying, pounding and mixing it with coconut toddy, as well as using it fresh. ${ }^{13}$ Seasonally, there were almonds, and coconuts were constant, though Mahaffy, who visited in the 1890s and later had a role in the island's administration, wrote in 1910 that 'cocoanuts are too rare and valuable to be lightly used, and the almonds are only ripe in their season'. ${ }^{14}$ Coconut was processed for its oil, which was perhaps more important in ceremonial use and also for toddy. As a textile, coconut provided all the material for the sennet fibre used in canoe and house building. Raobeia Ken Sigrah and Stacey M King also report the presence of mango, breadfruit and noni, especially along the coast. ${ }^{15}$ As well as these tree crops, islanders cultivated melons and pumpkins. ${ }^{16}$ One constant aspect of Banaban life was the occurrence of droughts, evidenced by rings on coconut trunks. ${ }^{17}$ Water was already scarce: there were no running streams and water was gathered from underground caverns by women using coconut shells. Like the land above them, particular water sources were owned by different families. ${ }^{18}$

While droughts occurred regularly and water became more and more difficult to find in the caves, in the early 1870s there was a three-year period in which no rain fell. ${ }^{19}$ Eri, of Uma, recalls this time when many were sick or dying of starvation, including his promised bride and his mother ${ }^{20} \mathrm{He}$, and most of the others still living, escaped on a passing ship, living in Hawai' $i$ until he was able to return. HE Maude and HC Maude call this moment when people fled the island 'The Great Dispersion' ${ }^{21}$ though many islanders found their way back in the following years. Mahaffy reports that the population prior to the 1870 s was thought to be around $1000 .^{22}$ In 1910, there were only 470 Banabans on the island, along with around 1000 others associated with the mine. ${ }^{23}$ In this climate, trees were especially precious.

\section{MINING COMMENCES}

\subsection{The Company identifies phosphate rock}

Australia, the UK and New Zealand were all involved in both the establishment and the continuance of phosphate mining on Banaba and Nauru. The Pacific Islands

11. Tekenimatang (n 4), 52.

12. Mahaffy (n 2), 5 .

13. Ellis (n 3), 76.

14. Mahaffy (n 2), 5 .

15. Raobeia Ken Sigrah and Stacey M King, Te Rii ni Banaba (University of the South Pacific, Suva 2001), 73.

16. Ellis (n 3), 76; HS and HE Maude (n 10), 76, 78.

17. Mahaffy (n 2), 5 .

18. ibid, 4 .

19. HS and HE Maude (n 10), 82.

20. ibid, 82-5.

21. ibid, 85 .

22. Mahaffy (n 2), 1 .

23. ibid, 2. 
Company Limited was the result of a merger between the John T Arundel Company and another company that dealt in trade goods, copra and pearl-shell, ${ }^{24}$ a typical nineteenth-century enterprise of the type operating across the Pacific.

Albert Ellis, a New Zealander, was working in the Sydney office of the company when he made a discovery that was to have a major impact on life on both Banaba and Nauru. What then emerged was not, however, typical in its scale and influence. Ellis had noticed a doorstop in the Sydney office, previously classified as fossilised wood, which resembled hard phosphate rock from another island. ${ }^{25}$ The material had come from Nauru, then known by outsiders as Pleasant Island, and upon testing was found to contain phosphoric acid. ${ }^{26}$ Since 'Ocean Island [Banaba] was known to be of like formation to Nauru, it was considered that a similar deposit would be found there'. ${ }^{27}$ Both islands are raised coral formations, and Ellis set out to determine the extent of phosphate rock on both of them. Ellis's own account of his role in the industry is a tale of derring-do rather like the adventure romances of the late-nineteenth century. $\mathrm{He}$ casts himself in the role of brave voyager heading out into parts unknown, returning victorious after 'Striking Oil' as he described it. ${ }^{28}$ Though he had previously been to both islands, they were quite remote from Sydney, and his manager warned him about Banaba: 'Those Ocean Islanders are hard cases. You take your rifle and revolver with you, and as soon as you get on the beach show the natives you can use them. ${ }^{29}$ Though no shots were fired, the visit was momentous in terms of life on the island. Without irony, Ellis notes that on his arrival on the 3rd of May $1900^{30}$ 'a scene of impressive pristine beauty rapidly spread out before us' ${ }^{31}$ Unfortunately, the unblemished view was to be short lived. From a prospecting point of view, the visit to Banaba was extremely simple:

The prospecting trip which followed was probably a record one for shortness and decisiveness; also in regard to the quality of the phosphate discovered. We passed through the native village, and a hole was sunk in the rising ground just beyond. The result was a most gratifying surprise, for not only was rock phosphate thrown up, but all the fine alluvial intermixed with it appeared to be phosphate also ... Proceeding inland about a mile, we sank several more holes at intervals, and in each instance nothing but phosphate turned up. A further gratifying feature was that in no case did we reach the bottom of the deposit. ${ }^{32}$

\subsection{Island authority and mining agreements}

According to Ellis, obtaining permission to work the phosphate was also entirely straightforward. In fact, he claimed 'There was no difficulty in the matter, as [the islanders] were eager to come into closer touch with civilization' ${ }^{33}$ It is unlikely that those with whom he negotiated had any real idea about what was being proposed.

24. Ellis (n 3), 51.

25. ibid, 52 .

26. ibid, 52-3.

27. ibid, 53.

28. ibid, 55-62.

29. ibid, 55.

30. Macdonald (n 1), 95.

31. Ellis (n 3), 59.

32. ibid, 57.

33. ibid, 58. 
Another factor which put Banabans at a disadvantage was the fact that, knowingly or otherwise, those negotiating with them failed to understand how authority functioned on the island, because, typically, Europeans entering the Pacific tended to look for single authoritarian figures, often portrayed as 'kings', even when such designations were quite at odds with actual forms of leadership and associated decision-making processes. ${ }^{34}$ Initial agreements were made with some, but not all Banabans. Ellis persuaded Temati, who is described on the agreement as the 'King of Ocean Island' to put his mark, as well as Kariatabewa, described as 'Chief'. ${ }^{35}$ These two were the only Banabans to make the initial agreement that ultimately and seemingly inevitably resulted in the almost complete destruction of the island as a habitable space. Ellis notes in his diary (not in his published account) regarding Temati that 'as his authority was undisputed, it was not considered necessary for any of the other natives to sign'. ${ }^{36}$ This tendency in Europeans to seek the one single 'king' can be seen as just one of many patterns of thinking in which Pacific societies were assumed to be less sophisticated than European ones, as well as to be inherently patriarchal and authoritarian in nature. The actual functioning of power on Banaba was much more complicated.

Barrie Macdonald notes sources that show how obvious this complexity was to outsiders. One such source draws upon the 1938 autobiography of the Resident Commissioner from 1913 to 1920 , EC Eliot, who wrote that

\begin{abstract}
About 1916 ... I took statements from three of the chiefs who were fêted in the s.s. Archer in 1900. The Company had tried to make out that the chiefs were the representatives for all island land held 'in common,' and could therefore lease the whole island on behalf of their subjects ... When it became known on the Island that the Company's representatives had made some 'paper' which was said to bear the marks of the chiefs, the islanders repudiated the document ...
\end{abstract}

Similarly, Macdonald records that a missionary, Rev. AC Walkup, who was visiting the island while Ellis was undertaking his initial prospecting, noted that 'the highest cheif [sic] signed their paper, but the other chiefs refused, saying the land belonged to the people'. ${ }^{38}$ It would have been difficult over the course of three weeks for Ellis not to have some awareness of this. In fact, Ellis eventually held talks with other chiefs and villages 'to offer them a share of the spoils'. ${ }^{39}$ Signed on 3 May 1900, the 'agreement' was to last for 999 years, and it promised to pay the 'said natives at a rate of fifty pounds $(£ 50)$ per annum or trade to that value at prices current in the Gilbert Group, payable half-yearly'. ${ }^{40}$ The agreement did not permit the removal of cultivated crops of fruit trees, but did allow unlimited access to build infrastructure, including jetties and tram lines. Finally, it allowed the company to import labour to work the mining operation. ${ }^{41}$

34. This is evidenced in the push by colonial powers in both Tonga and Samoa to establish 'kings', despite complex traditional chiefly lineages featuring competing titles and powers which existed in productive tension.

35. Macdonald (n 1), 96.

36. ibid.

37. ibid.

38. ibid, 97 .

39. ibid, 96.

40. ibid, 95 .

41. ibid. 


\subsection{Contemporary criticism of the Company}

The story of abuse and exploitation by a British firm of a small group of people from a little-known Pacific island may seem like an unremarkable one in the history of the colonial project, but it became infamous outside of the Pacific region. Missionaries and others complained to the British Parliament, to the Colonial Office and to the press. The exploitation underway was critiqued in the mainstream press of the day in both the United Kingdom and Australia. The Exchequer began paying the 'small royalty of the phosphates' to the Gilbert Protectorate Funds from 1 April 1909, as a result of the complaints about the Gilbert Islands' administration made to the Colonial Office. ${ }^{42}$ This gesture did little to tip the balance in favour of the Banabans: though they maintained traditional relationships with various islands of the Gilbert group, Banabans considered themselves to be owners of a sovereign island. At the same time, vast wealth flowed out of the island and principally into the pockets of Company men. As early as 1912, a writer in the Sydney Morning Herald foresaw the dilemma that would eventually see the islanders removed from the island:

An acute situation over the land question has been created at Ocean Island, and probably never before have the interests of mining and agriculture so decisively clashed. It has resolved itself into a fight for the survival or extinction of the phosphate quarrying industry at the island, either the phosphate industry has to go, or the whole of the population of the island, some 500, must be found some other abode. The position of affairs at the island just now is unique in history. ${ }^{43}$

The writer goes on:

The Ocean Islander saw his lands and only means of existence gradually disappear, leaving, instead of his palm and pandanus groves, worked-out quarries. Foreseeing the inevitable end, the natives some time ago definitely refused to sell any more lands ... Naturally some think the native owners are right, yet it is inconceivable that 500 Ocean Island born natives can be allowed to prevent the mining and export of a produc[t] of such immense value to all the rest of mankind. ${ }^{44}$

The reporter is aware that the Banabans were rapidly losing their island but was not prepared to say that this loss outweighed the benefits of phosphate mining. Resistance to losing any more land was at the time already apparent in the Banabans, who had been refusing sale for some time. The notion that another island would 'do' for them is a recurring one, and was already in play. The island being proposed at that time was Kuria in the Solomon Islands, also a British Protectorate. Such thinking reached its ultimate conclusion not in a plan to relocate the Banabans on Kuria but in their 1945 relocation to Rabi in Fiji.

Further criticism of the activities of both the Colonial Office and of the Company is seen a year later in a lengthy anonymous piece ('Modern Buccaneers of the West Pacific') published in the London weekly, The New Age. ${ }^{45}$ While the other islands in what was then The Gilbert and Ellice Islands were declared a British Protectorate

42. Anon., 'Modern Buccaneers of the West Pacific' (5 June 1913) 13(6) The New Age: A Weekly Review of Politics, Literature, and Art 136-40, 137.

43. 'Ocean Islanders: To Go or Not to Go? Bad Outlook for Natives', Sydney Morning Herald, 13 April 1912, 17; Katerina Martina Teaiwa, Consuming Ocean Island: Stories of People and Phosphate from Banaba (Indiana University Press, Bloomington 2015), 16-17.

44. 'Ocean Islanders: To Go or Not to Go? Bad Outlook for Natives' (n 43).

45. Anon., 'Modern Buccaneers' (n 42). 
in $1892,{ }^{46}$ such a declaration did not technically occur with respect to Banaba until 28 September 1901, after mining had commenced. ${ }^{47}$ The timing of the declaration seemed rather too convenient to the writer of 'Modern Buccaneers', and indeed it seems that Lord Stanmore, formerly Governor of Fiji and High Commissioner of the Western Pacific, then Chairman of the Pacific Phosphate Company, used his connections to agitate for formal annexation of the island. ${ }^{48}$ The writer of 'Modern Buccaneers' implicates Lord Stanmore both in the decision to delay the hoisting of the British flag until after mining negotiations were complete and therefore clear of any oversight, and in respect of the measly amounts paid to the islanders. In a highly critical piece, the writer asserts that 'The modern buccaneer is a very different type of individual, may be seen in public life in silk hat and frock coat, and often has never set eyes on the place he is looting. ${ }^{49}$ Calling the rent and royalty amounts 'absurd', the writer presents the functions of the Company, and the agreements it came to with both the Banabans and the British Government, as being dubious in the extreme: 'Unfortunately these phosphates, many tens of millions sterling in value, were, with the exception of a trifling royalty to the Imperial Exchequer, presented by the Colonial Office as a free gift to an Influential private company, some of whose members had held high positions in the Colonial Office Service!' ${ }^{50}$ Comparing the activities of the Company and the administration to those of the Belgians in the Congo, the anonymous writer also informs readers that the colonial administration assisted the Company in forcibly acquiring labourers for the mines from other islands in the Gilbert group. ${ }^{51}$

\section{LAND TENURE ON BANABA}

Banaba, at six and a half square kilometres, is not large. ${ }^{52}$ As Katerina Teaiwa notes, unlike much of the Pacific, and in marked contrast to Kiribati, land was not held in common: 'Each individual, male and female, adult and child, had their own carefully demarcated plots that they could keep, exchange or dispose of at will' ${ }^{53} \mathrm{HC}$ and $\mathrm{HE}$ Maude, using in part the papers of Arthur Grimble, outline at length the different circumstances under which land might be exchanged, inherited or forfeited. ${ }^{54}$ The authors provide an extensive list, which includes reparations for crimes against both person and property and payments for services. Crimes listed include murder and adultery, while services listed include being cared for during times of famine. ${ }^{55}$ That the basic justice measures in the culture were based on land indicates how integral land was to life on the island, not just for the provision of food but also as a foundational component of Banabans' complex social organization. The land of Banaba

46. Macdonald (n 1), 68.

47. ibid, 98.

48. ibid.

49. Anon., 'Modern Buccaneers' (n 42), 136.

50. ibid.

51. ibid.

52. Teaiwa (n 43), 5 .

53. ibid, 9.

54. HS Maude and HE Maude, 'The Social Organization of Banaba or Ocean Island, Central Pacific' (1932) 41(4) The Journal of the Polynesian Society 262-301, 288-92; K Teaiwa (n 43), 13. 55. ibid, 289. 
was not just a place to live, it was the basis of life in every way. One element of this list provided by Maude and Maude concerned frigate birds, and demonstrates just how important these birds were to Banaban life, and how highly regarded: 'Nenebon te Man. Should an individual kill any tame frigate or other bird belonging to another, one piece of land would be conveyed under the above title by the killer to the owner of the bird'. ${ }^{56}$

That land was the basis of everyday life was also reflected in Banaban negotiations with the Company in the years following the initial agreements. As Resident Commissioner Captain John Quayle Dickson wrote to the High Commissioner for the Pacific, Sir Henry May in 1911:

... the main idea seemed to be to preserve the island for their descendants; they said they had been foolish in the past in disposing of their land, but now realised the mistake they had made, as they had no idea when the company started operations that it would result in the devastation of their land. ${ }^{57}$

Whatever the Banabans thought about their negotiations with the Company, there was an inevitability about the attitudes of both the Company and the Colonial Office (which in the main supported the Company). The desire of the Banabans to 'preserve the island for their descendants', was obvious then, and has remained constant since.

\subsection{Company deceit}

There was ongoing conflict about the loss of fruit-bearing trees, and the aforementioned Dickson tended towards a pro-Banaban stance in negotiations with the Colonial Office and the Company. He was ignominiously removed but it was also soon apparent to his replacement, Edward Eliot, that the Company was often devious in its dealings with the Banabans. ${ }^{58}$ When the Banabans requested a survey of the leases - undertaken by a government surveyor from Fiji in 1914 who found that most were inaccurate and favoured the Company - this survey was paid for out of a newly created Banaban Fund. ${ }^{59}$ Similarly, when a price was put on trees, Eliot himself was guilty of a sleight of hand when he appeased the Company and paid his own suggested price per tree 'ranging from $4 \mathrm{~s}$ for a mature pandanus to 1s for a lime' - from the Banaban Fund, 'without the knowledge of the Banabans' ${ }^{60}$ Like many businesses dependent on imported labour, the Company had a monopoly on trade goods, and the range of prices depended on who was doing the buying. Such monopolies were another way of tying labour to the Company. Japanese tradesmen and Europeans were charged only half the prices that were extended to Banaban locals and to other imported labourers. When the Company agreed, under pressure, to make prices uniform for all, it then raised all prices and offered discounts to European staff. In response to these same discounts being offered to government officials, the Secretary to the Western Pacific High Commission, Vaskess, complained that the 'proposal looks ... uncommonly like an attempt to bribe the officials to allow further fleecing

56. HS and HE Maude (n 10), 66.

57. Macdonald (n 1), 101.

58. ibid, 100-101.

59. ibid, 102.

60. ibid. 
of the Banabans!' ${ }^{61}$ Not content with their high profit margins, an aura of greed for themselves and disregard for Banabans tainted the relationships of the Company men with the islanders.

This taint coalesced around the issue of the restoration and replanting of workedout lands. It was almost impossible to restore vegetation once the phosphate had been removed to reveal the coral pinnacles that underlay it. Soil was required but no real effort was made to bring it in. Even in areas that had not been mined the trees died because the soil around them was removed and their roots were interfered with. Drought finished off whatever small efforts were made. Eliot reported in 1917 that the scheme to replant was 'as dead as the trees which have been planted in the worked-out areas from time to time'. ${ }^{62}$

\subsection{The impact of World War I}

World War I had lasting effects on power relations in the Pacific. Following the exclusion of the Dominions from the Allies' Armistice arrangements, Australia's then Prime Minister Billy Hughes pushed for more influence for Australia. In particular, he urged that Australia should take control of all of Germany's former colonies in the Pacific. This would include Nauru, as well as German New Guinea and Western Samoa. Though this was not the final distribution, in the jockeying that followed, decisions were made about the control of phosphate mining on both Nauru and on Ocean Island. In 1919, the Nauru Agreement was drafted in Australia, giving three governments - those of the UK, Australia and New Zealand - control of the phosphate industry on Nauru and Ocean Island, with Australia and Great Britain each paying compensation of 42 per cent, and New Zealand 16 per cent, to the Company. ${ }^{63}$ This distribution would also be the division of the resulting prize: phosphate rock. After much disagreement, conflict and forceful lobbying, 'the Directors of the Pacific Phosphate Company accepted a final offer of $£ 3.5$ million' on 18 February $1920 .{ }^{64}$ The new company, operating through the British Phosphate Commissioners, then began to apply even more pressure to acquire Banaban land, directly approaching the Colonial Office for help. ${ }^{65}$

\subsection{Ongoing conflict over land and trees}

Negotiations over the next decade were to prove critical. The Resident Commissioner on Banaba at this time, Herbert McClure, cabled the Colonial Office in 1923 to warn it that the new 'application involves interference with one village and commencement of alienation of entire best food producing area both within 5 years. It is almost inevitable that eventually removal of Banabans elsewhere must follow. Anticipate vigorous protest by Banabans'. ${ }^{66}$

61. ibid.

62. ibid, 103 .

63. Maslyn Williams and Barrie Macdonald, The Phosphateers: A History of the British Phosphate Commissioners and the Christmas Island Phosphate Commission (Melbourne University Press, Melbourne 1985), 130.

64. ibid, 131.

65. Macdonald (n 1), 103.

66. ibid. 
Even when Buakonikai village was removed from the negotiation, resistance was strong, and was led by younger mission-educated men, including Rotan Tito, who became the voice of Banaba for the next half century. ${ }^{67}$ Another player also entered the 'negotiations' at the time: Arthur Grimble, later to become famous for accounts of his time in the Gilbert Islands, including A Pattern of Islands. At this point, Grimble was a frustrated junior colonial officer who had been appointed as a cadet in 1914 after an illustrious career at Cambridge University; he had been suffering from ongoing dysentery and had been seeking a transfer out for the whole of the previous decade. ${ }^{68}$ Grimble had been made the first Native Lands Commissioner for the Gilbert and Ellice Islands in 1920, and from 1926 he was also Resident Commissioner. Though untrained in anthropology, he undertook studies of local customs and then attempted to impose his understandings of customary law across the Gilbert and Ellice Islands - his version (described as 'draconic' by a fellow colonial officer in Fiji) overriding 'variations in local law in favour of an alien norm' ${ }^{69}$ Grimble also failed to register how quickly local culture was itself in a process of change. His facility in the local language perhaps gave him an inflated impression of his familiarity with the cultures of the various islands he dealt with: certainly, Barrie Macdonald, historian of the islands, describes Grimble's books about Kiribati as 'largely fictional' ${ }^{70}$ But the negotiations took place long before the books would be written. In this critical moment in the negotiations, Grimble was well-known by the islanders and was considered to be an intimate, probably because his capacity in Gilbertese inevitably gave him much greater access to local society than was available to other Europeans. Grimble was certainly not above attempting paternalistic manipulation of the islanders: Williams and Macdonald note an exchange between Grimble and Tito in 1927: 'When Grimble said that the rest of the Empire was "Holding out its hands to them, asking to be fed" ... Tito answered: "If the Empire wants our phosphate so badly, let the Empire pay $£ 5$ a car for it". ${ }^{71}$ While Grimble thought this to be 'either sheer greediness or a deliberately fanciful exaggeration' on the part of the Banabans,${ }^{72}$ it was neither. Tito's demand for $£ 5$ per ton indicated that the Banabans did not want to sell their land at all, as Macdonald acknowledges: 'For their part, the Banabans freely admitted that their demand of " $£ 5$ per car" was, in fact, a refusal to sell' ${ }^{73}$

The Banabans' counter-offer was definitely more than an ambit claim; after several decades of mining, they knew exactly what mining entailed: the complete destruction of their island. Grimble's letter to the people of the village of Buakonikai, written in their own language, came to light fifty odd years later during the Banaban case against the BPC and the British Government. ${ }^{74}$ In a threatening manner, Grimble had set out

67. ibid, 104-5.

68. Barrie Macdonald, 'Grimble of the Gilbert Islands: Myth and Man', in Deryck Scarr (ed), More Pacific Island Portraits (Australian National University Press, Canberra 1978) 212.

69. ibid, 223.

70. ibid, 229.

71. Williams and Macdonald (n 63), 226; K Teaiwa (n 43), 133.

72. Williams and Macdonald (n 63), 226.

73. Macdonald (n 1), 107. To read Macdonald is to read two different historians. In the 'official' history of the Company, The Phosphateers, Macdonald takes a different line to that of his history of Kiribati and Tuvalu, Cinderellas of the Empire, in which he is critical of company and colonial officials. This is partly explained by the fact that Maslyn Williams is responsible for the largely pro-Company Parts One and Two of The Phosphateers, with Barrie Macdonald the final third, a more neutral history of the Company since World War II.

74. Williams and Macdonald (n 63), 230; K Teaiwa (n 43), 134. 
'POINTS FOR LIFE. If you sign the agreement', the first of which is 'Your offence in shaming the Important Chief will be forgiven and you will not be punished'. Under 'POINTS FOR DEATH. If you do not sign the agreement' were listed further threats, beginning with 'Do you think your lands will not go? Do not be blind. Your land will be compulsorily acquired for the Empire'. Grimble finished his letter with further emotional intimidation: 'If you choose suicide then I am very sorry for you but what more can I do for you as I have done all I can. I am your loving friend and father' ${ }^{75}$ This was a major betrayal by 'one they had related to as "kin"'; it also frightened the Banabans, because the letter contained threats of unspecified punishment. ${ }^{76}$

\subsection{Compulsory land acquisition}

Following this impasse, legislation for compulsory acquisition of land by the British Government was then drawn up on the basis that whatever was under the surface of the ground, including the phosphate, 'belonged to the Crown'. ${ }^{77}$ That this was a 'reversal' of previous agreements and Colonial Office policy was clear. Full Banaban ownership of both the land and the 'minerals thereunder' had been stated policy until as late as 1923 , but by 1927 'ideals of this kind were considered to be not only fanciful but impractical'. ${ }^{78}$ What followed the Mining Ordinance of 1928 allowing for the compulsory acquisition of land for mining was the loss of both individual and collective agency for Banabans. ${ }^{79}$ Individual ownership of land was no longer recognized by the Company and royalties would not be paid to individuals but rather "paid directly to the resident commissioner to be held "on behalf of the former owners or owners"" ${ }^{80}$

\subsection{Women's resistance}

While male spokesmen like Tito were the public face of resistance, it was clear that much of their force came from powerful women, as was noted by both McClure and Grimble. In 1923 McClure wrote that 'it is the young men who appear to express the opinions of the majority. But behind them and most formidable of all is the feminine influence on which everything depends and which is entirely reactionary'. ${ }^{81}$ This was also the view of Grimble in 1927 - especially of Buakonikai village, where opposition was 'massive and abiding'. ${ }^{82} \mathrm{He}$ wrote that 'Women, especially owners within the proposed new area, arbitrarily and blindly opposed at present to transfer of land under any conditions whatever' ${ }^{83}$ Obviously this was a negative response to the role of women by these white administrators, but Macdonald conjectures that as women had not worked for the Company, but had landowning and speaking rights, they were inherently more conservative about retaining land ownership. ${ }^{84}$

75. K Teaiwa (n 43), 134-5.

76. ibid, 135 .

77. Williams and Macdonald (n 63), 227.

78. ibid.

79. Macdonald (n 1), 108.

80. K Teaiwa (n 43), 135.

81. Macdonald (n 1), 107; K Teaiwa (n 43), 132-3.

82. Macdonald (n 1), 107; K Teaiwa (n 43), 133.

83. Macdonald (n 1), 107.

84. Macdonald (n 1), 108. 
In addition to this account of female power in resistance, Katerina Teaiwa notes the particular role played by feminine entities in Banaban life more broadly. The land itself was described as 'Banaba, te aba $\mathrm{n}$ aine' (Banaba, the women's land), understood firstly as 'a peaceful land, free of war', but also referring to 'the active participation of women in politics before the arrival of Christianity and the advent of mining'. ${ }^{85}$ (Martin Silverman claims that 'Ocean Island is referred to by the people as "the woman's land", because of the people's disinclination to violence in contrast with some Gilbertese, who "love to fight". ${ }^{86}$ ) Clearly, at the time when mining began, Nei Teienemakin, mentioned at the start of this article, was considered to be a Queen by those who met her. Teaiwa also mentions the 'main surviving ancestral deity', Nei Tituabine, 'a female embodied by the stingray and lightning', ${ }^{87}$ both quick and powerful entities. Banaban culture has a variety of sources for understanding females as powerful and resourceful. But Banaban women also had completely tangible reasons for wanting to preserve their lands and everything that grew there: it was life and livelihood.

One of the most poignant stories in the whole sorry account of Banaban dispossession and the environmental degradation of the island came after the previously discussed failed negotiations. Macdonald relates that, 'Later, when the BPC tried to take possession of its compulsorily acquired lands, it was the women who clung to the trees in an attempt to prevent them from being destroyed' ${ }^{88}$

\section{RELOCATION TO RABI}

In 1945, the much-anticipated act of moving the remaining islanders of Banaba finally occurred. It had been mooted as early as 1909, when Mahaffy, as assistant to the High Commissioner on Ocean Island, wrote a confidential letter to the High Commissioner of the Western Pacific, stating that "A time must come when an "impasse" will be reached, and either the Company will have to abandon their work, or the natives will have to be moved off the island, which will no longer produce native food adequate for their wants' ${ }^{89}$ Similarly, John Quayle Dickson, Resident Commissioner, wrote later that same year to the High Commissioner, also confidentially, suggesting that the Banabans would need 'a very fertile island with a permanent water supply ... affording them food and profitable occupation at the making and export of copra' ${ }^{90} \mathrm{~A}$ decade later, $\mathrm{CH}$ Rodwell, High Commissioner, wrote to the Secretary of State for the Colonies that exploiting Ocean Island was an imperial duty: 'Indeed the interests of the Empire seem to demand that the process of development on Ocean Island should be allowed to continue until the whole island is worked out'. ${ }^{91}$ This approach would preclude ongoing life for Banabans on their island. The air of inevitability about this,

85. K Teaiwa (n 43), 133.

86. Martin G Silverman, Disconcerting Issue: Meaning and Struggle in a Resettled Pacific Community (Chicago, University of Chicago Press 1971), 183.

87. ibid.

88. Macdonald (n 1), 107.

89. Jane McAdam, 'Historical Cross-Border Relocations in the Pacific: Lessons for Planned Relocations in the Context of Climate Change' (2014) 49(3) The Journal of Pacific History 301-27, 307.

90. ibid.

91. ibid, 308. 
reflected by both Company representatives and colonial administrators, came to a head in the aftermath of World War II.

The Resident Commissioner on Ocean Island had pushed the Company to set up the Banaban Fund as early as 1913 'for the purpose of purchasing and providing a new home for the settlement of the Banabans when the progress of phosphate mining in Ocean Island should render necessary their emigration from that island' ${ }^{92}$ By 1940 , the Banabans themselves were considering the possibility of relocation to a place where they could 'resume native cultivation, mat-making and fishing', as life on the island was being overwhelmed by the European Company presence, as noted in a letter to the Secretary of State for the Colonies. ${ }^{93}$ After considering Wakaya in Fiji, rejected because of a lack of water and fertile soil, a decision was made by colonial officials to select Rabi, Fiji. Geographically, Rabi is quite different to Banaba, being a much larger volcanic island with a much higher rainfall; the island is 463 metres high, 66 square kilometres, and 2100 kilometres away from Banaba: ${ }^{94}$ 'nine times as large, six times as high, and five times as wet', ${ }^{95}$ as Silverman notes.

The history of Rabi is itself a complex colonial tale of ongoing dispossession. I largely follow the account given by Wolfgang Kempf and Elfieda Hermann here.

'Ownership' of the island had moved out of Fijian hands in the nineteenth century, passing to Tonga and then to John Hill and the Dawson brothers from Sydney. Ownership had come to the Tongan Government through the Tongan chief, Ma'afu, who had 'won' it in regional power plays; ${ }^{96}$ Tonga had long held sway over areas of Fiji, especially in the Lau islands. Hill, for his part, ran copra plantations, bringing labour to work them, first from Tanna in Vanuatu and then, in 1879, from India - the first such workers to come to the Fiji Islands. Josiah Smale then purchased the island in 1890 , leasing it to other companies, including Levers' Pacific operations. Smale's wife Helen eventually sold Rabi to Levers in $1924 .{ }^{97}$ Finally, the island was bought by the Western Pacific High Commission for the Banabans in March 1942, using the Banaban Provident Fund, ${ }^{98}$ for $£ 25,000 .{ }^{99}$ William Lever, who became Lord Leverhulme in 1911, when he was 'the most influential member of the board' ${ }^{100}$ had made significant investments in the Company, and the sale could not be seen as a 'coincidence', ${ }^{101}$ though he had by then been succeeded by his son. Jane McAdam points out the actual limits of Banaban ownership: 'While in land law terms the Banabans "owned" Rabi and Ocean Island, in international and constitutional law terms, those islands belonged to the crown - respectively Fiji (independent from 1970) and the Gilbert and Ellice Islands Colony (for which the UK government was

92. ibid, 309 .

93. ibid, 310 .

94. John Connell and Gil Marvel Tabucanon, 'From Banaba to Rabi: A Pacific Model for Resettlement?' in Susanna Price and Jane Singer (eds), Global Implications of Development, Disasters and Climate Change: Responses to Displacement from Asia Pacific (New York, Routledge 2015), 91-107, 97.

95. Silverman (n 86), 160.

96. K Teaiwa (n 43), 18.

97. Wolfgang Kempf and Elfieda Hermann, 'Reconfigurations of Place and Identity: Positionings, Performances and Politics of Relocated Banabans in Fiji' (2005) 75(4) Oceania 268-386, 383-4.

98. McAdam (n 89), 310.

99. Macdonald (n 1), 111.

100. K Teaiwa (n 43), 129.

101. ibid, 19. 
responsible internationally)' ${ }^{102}$ Constraints put in place by colonialism remained. Few of the accounts of the Banaban transfer to Rabi involve any mention of the original inhabitants of Rabi, but the inhabitants had suffered dispossession, as Katerina Teaiwa points out: 'Many of the descendants of the Fijian Rabeans, who lost their island, live on islands surrounding Rabi and have maintained strong ancestral links to their home island ... Rabi is thus a still-contested place with two displaced populations who call it home'. ${ }^{103}$ (While present day Banabans on Rabi try to maintain good relations with the people now located on the neighbouring island of Taveuni, there are understandable tensions. ${ }^{104}$ ) This transfer of Rabi, lauded by some as an ideal example of dealing with environmental devastation, is not as simple as it appears, and is hugely affected by traditional inter-island relationships as well as colonial ones. But before the Banabans could be finally persuaded to move, the Japanese intervened.

\subsection{World War II and relocation}

Just prior to the obviously imminent Japanese invasion in World War II, the Company prioritized two things: the demolition of the mining operation in order to stop the Japanese exploiting the phosphate, and the evacuation of European (226) and Chinese (597) workers, which was accomplished using a small French Cruiser and the commission's motor ship Trienza. ${ }^{105}$ In an article about the wonders of phosphate on New Zealand farms, Ellis boasted that this evacuation was accomplished 'without the loss of a single life'. He also claims that 'Unfortunately it was impossible to remove the native inhabitants'. ${ }^{106}$ This was not accurate, however, and it is difficult to see why he made the claim, other than in response to an impulse to paint the Company in a better light. As well as the Banabans and Gilbertese workers, the Company also left 'a small group of Europeans, including the acting resident commissioner, two labour supervisors, and a Catholic priest and Brother', leaving a total of 2413 people on the island when 550 Japanese invaded in August 1942. ${ }^{107}$ The occupation was brutal, with all of the British and many islanders dying, including a large number - 'over a hundred' - Gilbert and Ellice Islands men who were put to death after news of the Japanese surrender had reached the island. ${ }^{108}$ Prior to this final act, with poor access to food supplies, most of the community had been dispersed by the Japanese into internment camps on the islands of Kosrae, Tarawa and Nauru. ${ }^{109}$ The remaining Banabans and Gilbert and Ellice Island labourers then bore the brunt of the occupation, involving near starvation and acts of mindless cruelty, including islanders being forced to run to their deaths into an electrified fence, shootings and beheadings. ${ }^{110}$ Julia B Edwards, citing Maude and Maude, claims that a third of the population

102. McAdam (n 89), 310, n 52.

103. K Teaiwa (n 43), 19.

104. ibid, 173.

105. Arthur Ellis, 'New Zealand Farms and the "Phosphate Islands"” (1948) 4(1) New Zealand Geographer 55-68, 61.

106. ibid.

107. K Teaiwa (n 43), 140; Connell and Tabucanon (n 94), 97.

108. K Teaiwa (n 43), 141.

109. Julia B Edwards, 'Phosphate Mining and the Relocation of the Banabans to Northern Fiji in 1945: Lessons for Climate Change-Forced Displacement' (2014) Journal de la Société des Océanistes 121-36, 124; K Teaiwa (n 43), 14.

110. K Teaiwa (n 43), 141; Edwards (n 109), 124. 
died during the three years of the occupation. ${ }^{111}$ After the war, the British Government assembled the remaining Banabans on Tarawa, telling them that 'they could not return to Banaba'. ${ }^{112}$ The trauma of the combined circumstances of exile and extreme hardship no doubt added to the pressure being applied by the British for the relocation. Macdonald lists the factors that made it easier for Banabans to accept resettlement to Rabi: destruction from the war; drought and hardship; high mortality; and the dispersal of families during the Japanese occupation. ${ }^{113}$ The fact that all four villages on Banaba had been destroyed could not have helped. ${ }^{114}$

\subsection{Arrival at Rabi}

While some preparations were made by the British Government for the arrival of the Banabans on Rabi, somehow the authorities were not expecting the numbers that arrived. Edwards records an unpublished letter, written by L Verrier to the Director of Medical Services to the Banabans at the start of 1946, stating that 'about 700 people were expected, but latest advices mentioned 900 and they landed 1,003'.115 The evacuees arrived on 15 December 1945 via the Company ship Triona, Silverman recording that of the 703 Banabans and 300 Gilbertese, almost half were children. ${ }^{16}$

Maude reports that the Gilbertese were relatives and friends of the Banabans. ${ }^{117}$ Many Gilbertese had been working in the phosphate industry on Banaba and were married to Banaban women or had become connected to Banabans during the war. ${ }^{118}$ The island of Rabi had been set up as a copra plantation, with few facilities: there was no town; the plantation lacked 'basic infrastructure' and there were no immediate employment prospects. ${ }^{119}$ Tebora Tewai reported to Jane McAdam that the evacuees began life there living in tents, with only two months' supply of food and 'little knowledge of how to plant the island and become self-sufficient'. ${ }^{120}$ Makin Corrie Tekenimatang, a teenager when she arrived on Rabi, records that not only were the new arrivals surprised by the basic conditions but that not long after they arrived, a cyclone blew away tents and wrecked newly planted crops. ${ }^{121}$ The newcomers had of necessity neglected many skills on Banaba with the loss of land and the accompanying enforced reliance on imported goods. On Rabi, the very different climate required new skills. With good farming land and little else, the evacuees soon began to grow new crops such as 'copra, kava, taro, and cassava', and to return to traditional fishing. ${ }^{122}$

111. Edwards (n 109), 124.

112. Edwards (n 109), 125.

113. Macdonald (n 1), 111.

114. Connell and Tabucanon (n 94), 98.

115. Edwards (n 109), 125.

116. Silverman (n 86), 162.

117. Jane McAdam, 'Self-Determination and Self-Governance for Communities Relocated across International Borders: The Quest for Banaban Independence' (2017) 24 International Journal on Minority and Group Rights 428-66, 430.

118. Silverman (n 86), 162-3.

119. Edwards (n 109), 132.

120. McAdam (n 89), 312.

121. Makin Corrie Tekenimatang, 'Nei Makin', in Jennifer Shennan and Makin Corrie Tekenimatang (eds), One and a Half Pacific Islands: Stories the Banaban People Tell of Themselves (Wellington, Victoria University Press 2005), 64-70, 69.

122. K Teaiwa (n 43), 19. 
A new administrative structure was established under the Banaban Settlement Act by the Fijian colonial government, and under it the heads of families formed an island council for local government. ${ }^{123}$ Six months after the arrival of the evacuees this council decided to move out of the temporary campsite to the four villages on Rabi, and after a year, renamed them for the former villages on Banaba - Tabwewa, Buakonikai, Uma and Tabiang - in an act of acclimatization. ${ }^{124}$ Harry Maude claimed that the move was to be for 'a trial period of two years', ${ }^{125}$ after which the people could decide if they wanted to return or stay. Rabi resident Corrie, who was interviewed by Julie B Edwards in 2011, claimed that in 1946 community representatives returned to Banaba 'to assess, as they thought, the rebuilding process'. ${ }^{126}$ Archives show that the actual purpose was for 'the 149 landowners ... to register their land boundaries' in preparation for mining. ${ }^{127}$ The community representatives found an unrecognizable landscape on Banaba, with land completely cleared and all of the Banaban buildings removed. Corrie claimed that 'it was then that the Banabans realized that it was not the Japanese who had destroyed their home island, it was the undertakings of BPC'. ${ }^{128}$ The BPC of course had Banaba to itself and recommenced mining in 1947. ${ }^{129}$ On 13 May of the same year the Banabans held a secret ballot and decided overwhelmingly to remain on Rabi. ${ }^{130}$ In no way was this a decision to give up Banaba, as is made clear in the 'Statement of intentions of government', which included the assertion of 'an inalienable right to return to Ocean Island, respecting this deep-seated feeling ... of the Banabans for their land, and covered both the right of ownership and the right of access to the island'. ${ }^{131}$

\subsection{Autonomy and independence}

From 1948, Banabans began appealing for independence from both Fiji and from the Gilbert and Ellice Islands Colony, requesting that oversight of Banaba and Rabi should be from the Rabi Island Council only and through the Governor in Suva to the British Government. ${ }^{132}$ This appeal was rejected by the Governor under the Statement of Intentions ${ }^{133}$ but it indicates an ongoing Banaban desire for self-determination and autonomy, which only intensified over the following decades, fuelled by the independence movements of the 1960s, the resulting independence of Nauru in 1968, and also by the fact that the Gilbert and Ellice Islands Colony was getting the majority of the proceeds from ongoing mining on Banaba. ${ }^{134}$ Citing the High Commission papers, Jane McAdam notes that the independence claim was based on the following four points:

123. Edwards (n 109), 126.

124. Edwards (n 109), 126; K Teaiwa (n 43), 19.

125. McAdam (n 89), 313.

126. Edwards (n 109), 126.

127. ibid.

128. ibid.

129. Edwards (n 109), 126.

130. McAdam (n 89), 314.

131. ibid.

132. McAdam (n 117), 437-8.

133. ibid, 438.

134. ibid. 
1. They were a different people from the Gilbertese;

2. Banaba had been forcibly co-opted into the Gilbert Islands without consultation;

3. Banaba was not governed by the Gilbertese until the 20th century; and

4. Since the Ellice Islanders had been permitted to become the independent State of Tuvalu, they should also be allowed to become independent. ${ }^{135}$

Consistently, these are the grounds from which Banaban claims for autonomy have been made. McAdam suggests that the increasingly strident stance against the Gilbertese Government was largely forced on Banabans once they began using the framework of international law, especially when evoking the idea of the nation state for the purposes of recognition. ${ }^{136}$ Despite centuries of interrelationship, including kinship with people from these neighbouring islands, Banabans needed to be seen as being quite separate from Kiribati in order to be seen at all. ${ }^{137}$ But the extreme reaction by the Banabans also had another underlying cause: 'denial of Banaban land rights, or rather the perception of a denial by the Gilbert Islands administration or anyone else, is one of the most provocative acts which can be committed. It is almost equivalent to denying that Banabans exist'. ${ }^{138}$

\section{SEEKING JUSTICE}

The Banabans had earlier been offered 'an ex gratia payment of $£ 100000$ ' by the British Government, but refused it because the payment was termed as being 'in consideration of the effects of phosphate mining upon Ocean Island since 1900'. ${ }^{139}$ The amount offered was regarded as being an inaccurate representation of the devastation of the island, quite apart from being entirely inadequate compensation compared to the profits purloined from mining. This disparity added to resentment about the Company use of the Banaban Fund without consultation, ${ }^{140}$ and the sense that on Rabi, Banabans were sidelined from the fate of their island. When a Banaban group visited Banaba in 1967, they were most concerned about the restoration and replanting of mined areas, and some members of the group tried to physically stop the mining operation. ${ }^{141}$ Having threatened to do so for some time, in April 1968 the Rabi Council of Leaders approached the United Nations, and in June of the following year a delegation made a presentation to a sub-committee of the United Nations Committee of Twenty-Four, petitioning for 'an immediate return to Ocean Island, political independence for the Banaban people on Ocean Island, a deferral of any increase in output at the island, and immediate and full rehabilitation of all worked-out areas' ${ }^{142}$ Despite this action resulting in a generally supportive list of resolutions, no recommendation was made in favour of independence and no corresponding action came from the United Kingdom. ${ }^{143}$ Williams and Macdonald describe the lack of action on the

135. ibid, 439.

136. ibid.

137. ibid.

138. Silverman (n 86), 187.

139. Williams and Macdonald (n 63), 507.

140. ibid, 508.

141. ibid.

142. ibid.

143. ibid. 
part of the UK as being 'in accordance with the longstanding refusal ... to allow the United Nations to "interfere" with its colonies'. ${ }^{144}$ As time passed, the sense of grievance became more desperate for many Banabans.

\subsection{Tito $v$ Waddell}

Ultimately this discontent resulted in writs being issued in November 1971 for \$120 million against the Government of the United Kingdom and against the Company Commissioners. ${ }^{145}$ Tito $v$ Waddell was the 'longest civil hearing in British legal history', ${ }^{146}$ and included the members of the court making a trip to Banaba at the invitation of Tebuke Tito ${ }^{147}$ (leadership of the community had passed from father to son). In the action against the Company, 'the Commissioners were sued for a breach of contractual replanting obligations dating from $1913 \ldots$.., compensation for the unauthorized mining of areas totalling about 15 acres and unauthorized removal of sand from a Banaban cemetery'. ${ }^{148}$ In the other writ, against the Attorney-General of the UK, 'the Banabans alleged that Britain had failed in its duty as trustee for the Banaban people during the compulsory acquisition procedures of 1931 and the land negotiations of 1947', together with further allegations about pricing and royalties. ${ }^{149}$

One of the more sensational revelations to emerge during the trial from the perspective of the British press concerned Arthur Grimble's role in pressuring the Banabans during the tense stand-off between the Company and the islanders in 1928 that eventually resulted in compulsory acquisitions. Though he had died in 1956, Grimble was famous around the world for his books and broadcasts, and was widely seen as the model colonial administrator. When the letter of 5 August was tabled (referred to above in Section 4.3), the extent of his betrayal of the Banabans was made clear. ${ }^{150}$ Originally in Gilbertese, the translation showed those in Britain just how manipulative and threatening Grimble had been at the time.

Ultimately, in the case against the Crown, Justice Robert Megarry could only make a judgment based on the notion of legal, rather than moral trust, and thereby found that the British Government was not a trustee for the Banabans. ${ }^{151}$ His final statement was: 'I think a judge ought to direct attention to what he considers to be a wrong that he cannot right, and leave it to the Crown to do what is considered to be proper'. ${ }^{152}$ This dictum meant that the Crown was 'not liable for the injustices committed in their name'. ${ }^{153}$ In the case against the Company, Megarry noted that though the obligation of replanting did pass from the Pacific Phosphate Company to the BPC, 'the actual replanting of the lands' was not required, though compensation for the failure to do so was necessary. ${ }^{154}$ The Banabans requested AU $\$ 11$ million in total (AU\$73,140 per acre). The BPC offered AU $\$ 3,000$ per acre. When an agreement could not be reached

144. ibid.

145. ibid, 505.

146. Macdonald (n 1), 268.

147. Binder (n 8), 156.

148. Williams and Macdonald (n 63), 511-12.

149. ibid, 512.

150. Binder (n 8), 154-5; K Teaiwa (n 43), 134-5.

151. Macdonald (n 1), 269.

152. K Teaiwa (n 43), 146.

153. Edwards (n 109), 126.

154. Macdonald (n 1) 269. 
between the parties, Megarry, rather than finding some middle point in these admittedly disparate amounts, ruled that 'an appropriate sum by way of damages is \$A75 per acre'. ${ }^{155}$ This amounted to only AU $\$ 11,000$ in total. ${ }^{156}$ In drawing attention to the Crown's moral obligation, Megarry noted in particular Grimble's coercion in 1928 and the post-war failure to give adequate advice to the Banabans when negotiating further mining in $1947 .{ }^{157}$ Following the outcome of the case, the three governments partnering in the BPC offered a AU\$10 million payment 'to establish a fund for social and economic development'. ${ }^{158}$ The Banabans determinedly rejected the offer until such time as they could gain independence from the Gilbert Islands and be established as a self-governing nation 'in free association with Fiji', a notion that had been increasingly floated by them. ${ }^{159}$ Some Banabans expressed their frustrations in 1979 by sending a 'war party' to Ocean Island, bombing mining works and fighting with Gilbertese police; one Banaban was killed. ${ }^{160}$ Those in the Gilbert Islands were increasingly annoyed by the delays these issues caused in their attempts to gain independence from Britain.

The Banabans were not to win independence for Ocean Island. Eventually, after Gilbertese independence was declared in 1979, the Banabans accepted the payment, though they did not use it until 1984, when 'poverty on Rabi forced them to accept'. ${ }^{161}$ The island of Banaba was now part of the new nation, the Republic of Kiribati, which received all the 'phosphate reserve funds', ${ }^{162}$ earnings today worth US $\$ 400$ million. ${ }^{163}$

\subsection{Spatial justice}

If, as asserted by Edward W Soja, spatial justice involves 'the fair and equitable distribution in space of socially valued resources and opportunities to use them' ${ }^{164}$ it raises the question of resources such as phosphate rock, the places in which it has been mined and the rights of the people who live in those spaces. What does fairness look like in this circumstance, especially in the context of the loss of ancestral lands? Because thinking around spatial justice and society has been primarily focused on the city as its site of analysis, ${ }^{165}$ the way in which it might play out in the context of colonized spaces and empires away from urban centres is harder to envisage. What would spatial justice look like now in the Banaban case? How can 90 per cent of an island's soil, including the bones of the ancestors, ever be returned, restored and replanted?

155. ibid.

156. ibid.

157. ibid.

158. ibid.

159. ibid.

160. K Teaiwa (n 43), 148.

161. ibid.

162. ibid, 147.

163. ibid, 170 .

164. Edward W Soja, 'The City and Spatial Justice' (September 2009) 1 Spatial Justice <http:// www.jssj.org>.

165. See for example the following: David Harvey, Social Justice and the City (Edward Arnold, London 1973) and Edward W Soja's development of his ideas in 'The City and Spatial Justice' (n 164) and Seeking Spatial Justice (University of Minnesota Press, Minneapolis 2010), amongst other texts. 
The nigh impossibility of this ever happening is an ongoing source of grief to Banabans.

\section{A LEGACY OF GRIEF}

The loss to Banabans encapsulated in the circumstances outlined in this article was not just experienced in the past. Contemporary Banaban identity is experienced as 'an ontology of space' 166 in which being is formed in part around community anguish. This formation of identity is captured in the account that Taomati Teai, a grandson of Rotan Tito, gives of the Banaban motto. The first council on Rabi established their motto as 'Our God, Our Help', but this was later changed to reflect their increasing distress: 'Atuara Buokira ... is actually the people crying out ... Please help us'. 167

I turn now to a contemporary response to these histories and the griefs that they evoke as explored in Katerina Teaiwa's art installation Project Banaba.

\subsection{Project Banaba}

Of Banaban and I-Kiribati descent, artist and academic Katerina Teaiwa's Project Banaba presents aspects of her research on Banaba as an art installation. While some of this work is otherwise found in academic publications, ${ }^{168}$ the exhibition makes use of sources that are not easily accessed in that form, such as video and personal photographs. Shown at Carriageworks, Sydney, in November and December 2017, ${ }^{169}$ and again at MTG Tai Ahuriri, Hawke's Bay, Aotearoa/New Zealand, from March to September 2019, ${ }^{170}$ the installation utilizes three forms: photographic image, film with sound and work in fibre. Described by Michael Fitzgerald as a 'multimedia event' ${ }^{171}$ these sources distil many of the most pertinent and poignant aspects of the Banaban story, especially the dispersal of 'te aba, the body of the land', ${ }^{172}$ as the basis of Banaban society and identity. It took 'millions of years ... to build up the phosphate rock' ${ }^{173}$ but only 80 years to remove almost all of it.

In a darkened Carriageworks, the first sense the viewer has of the exhibition is the large textiles and photographs suspended from the ceiling, dividing the space (Figure 5); these, together with the wall text, are entitled Body of the land, body of the people.

166. Soja, Seeking Spatial Justice (n 165) 67.

167. Wolfgang Kemp and Toamati Teai, 'Banaban Routes and Roots - a Dialogue', in Jennifer Shennan and Makin Corrie Tekenimatang (eds), One and a Half Pacific Islands: Stories the Banaban People Tell of Themselves: Teuana ao teiterana $\mathrm{n}$ aba $\mathrm{n}$ te Betebeke: I-Banaba aika a karakin oin rongorongoia (Victoria University Press, Wellington 2005), 124-7, 126; K Teaiwa (n 43), 149.

168. The most significant of these is the previously cited Consuming Ocean Island: Stories of People and Phosphate from Banaba (Indiana University Press, Bloomington 2015).

169. Project Banaba Media Release, 25 September 2017, Carriageworks, Sydney.

170. Katerina Teaiwa, 'Project Banaba', Tautai: Guiding Pacific Arts <http://www.tautai.org/ project-banaba/> accessed 28 July 2019.

171. Michael Fitzgerald, 'Remaking Culture in Project Banaba: Katerina Teaiwa in Conversation with Michael Fitzgerald', Art Monthly No. 304, Summer 2017-2018, 48-51, 48.

172. K Teaiwa (n 170).

173. K Teaiwa in Fitzgerald (n 171), 48. 


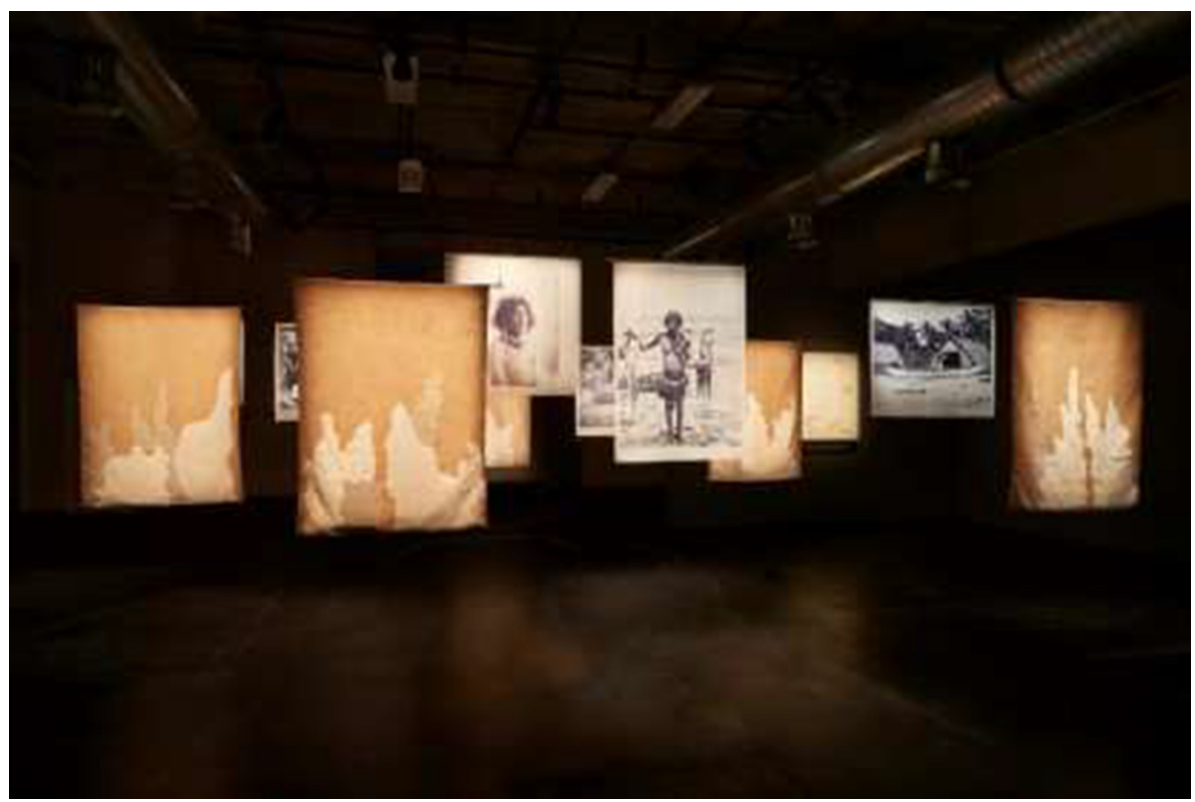

Figure 5 From Project Banaba, Katerina Teaiwa, Carriageworks, Sydney. Image by Zan Wimberley. Used with permission

The photographs are archival and were taken in the era in which the mine was established, showing Banabans in a range of settings: emerging from the sea after catching octopus; men in celebratory dress for dancing; a group of children in white shirts on the veranda of a colonial house, and a shot featuring a range of men and women, young and old, wearing traditional or Western-influenced dress, including the ubiquitous Mother Hubbard, ${ }^{174}$ so favoured by missionaries in the Pacific. There are also images of Banaban houses and outrigger canoes. Between these images are similar sized hangings in two types of fabric, calico and hessian. Calico was the material used both for colonial staff uniforms and company staff and worker uniforms. ${ }^{175}$ Here it has been appliqued onto hessian in shades of fawn depicting the coral pinnacles left after removal of soil in the phosphate mining process. These pinnacles now dominate the landscape of Banaba, and the viewer must walk through the landscape of the gallery with them right in their sightline. Hessian sacking evokes the material in which the phosphate was transported when mining began. ${ }^{176}$ Many of the hessian sheets are printed with the company's Australian trading name, 'Pivot Fertilisers: the Phosphate Trading Company of Australia', followed by a salient fact, date or quotation from the archival records of the company (Figure 6). In brief, these convey the often shocking nature of the imperial exercise on Banaba, and include excerpts from Grimble's misguided and manipulative letter, sent to coerce the islanders in 1928 when they had had enough of the devastation

174. Sally Helvenston Gray, 'Searching for Mother Hubbard: Function and Fashion in Nineteenth-Century Dress' (2014) 48(1) Winterthur Portfolio 29-74.

175. Mitiana Arbon, 'Project Banaba (review)' (2019) 31(1) The Contemporary Pacific 238-41, 239.

176. ibid. 
Journal of Human Rights and the Environment, Vol. 12 No. 1

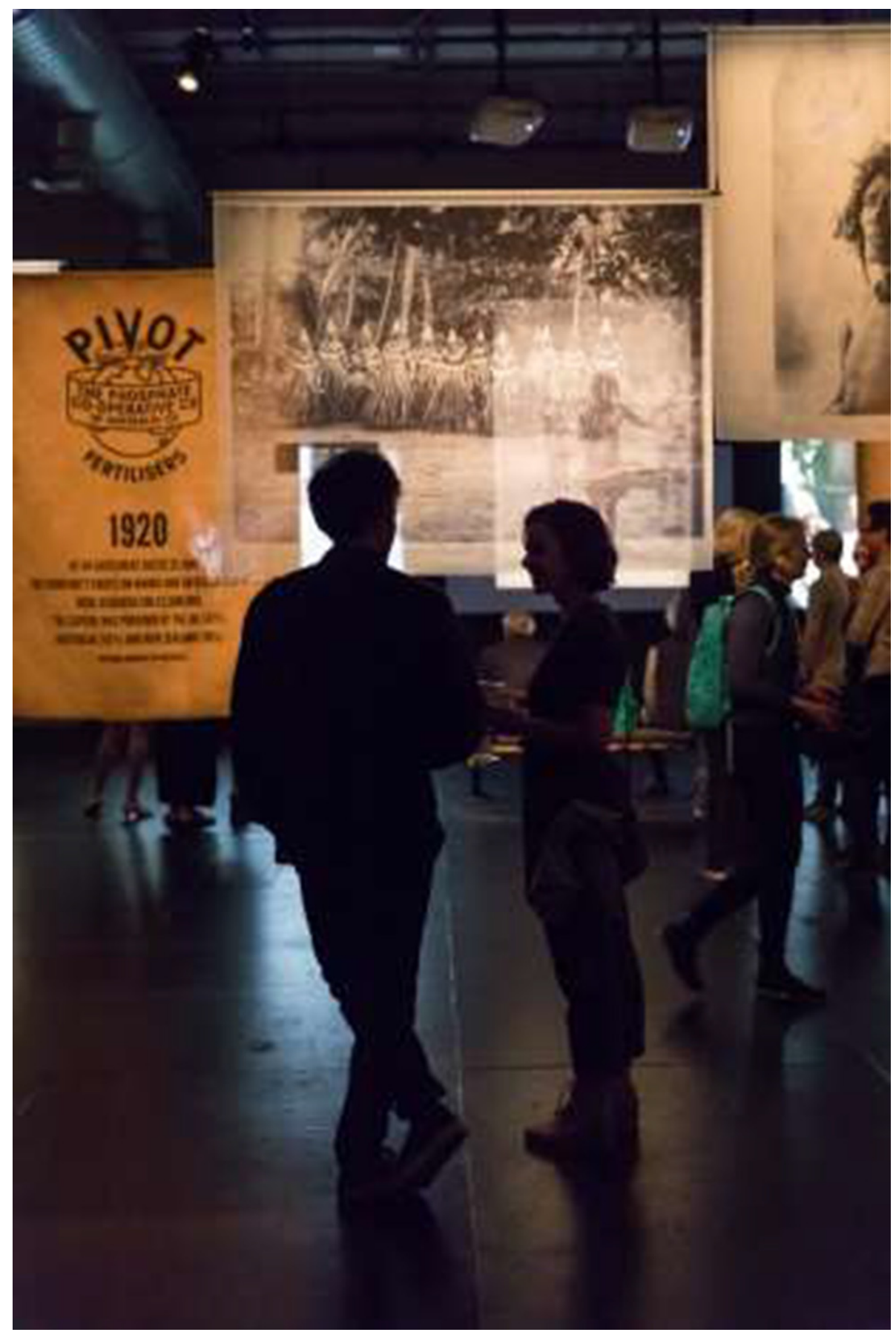

Figure 6 From Project Banaba, Katerina Teaiwa, Carriageworks, Sydney. Image by Zan Wimberley. Used with permission 
and had refused to give up more of their land. The poignancy of the hessian is enhanced by the fact that it also bore the remains of ancestors off the island to be spread throughout the world as fertilizer. The second element, a photographic reef, Teaiwa's Kainga, is hung salon style on one wall, lit for emphasis (Figure 7). The reef includes images taken on Banaba by Teaiwa, but predominantly features Teaiwa family images, many of the photographs having been taken on Fiji. Some show the new Banaban villages on Rabi where life continues. A map showing the routes taken by the artist in her research also reflects the routes taken by both phosphate and company employees.

The final element of Project Banaba is the trio of video screens on the far wall, Mine Lands, for Teresia (Figure 8). Initially, to the soundtrack of the catchy theme song from Peter Russell-Clarke's Come and Get It cooking show (popular on Australian television in the 1980s), the central screen depicts a montage of life on Banaba during the colonial mining era: a busy harbour, bustling general store, shirtless Pacific workers moving bags of phosphate, trains and conveyor belts shifting more bags, and phosphate being loaded onto ships. There are vignettes of expatriate colonial life: a brown servant serving white ladies, games of golf and tennis, a white woman greeting white guests, white men swimming. This is interspersed with quick edits of headstones of people from both the Pacific and beyond, and the now desolate scenes of the island. The montage ends with the newspaper headline 'Farmers Reap Benefits', fittingly shown after an image of sheep on lush green grass. It is not hard to draw the connection between mining activities on Banaba and food on the table in Australia, New Zealand and Britain. Further historical footage is seen on all three screens, with colour indicating the era. The soundtrack is often telling its own story, as when the sound of clapping or slapping is heard over images of islanders and Chinese labourers working for the Company. The methods of shifting phosphate become more

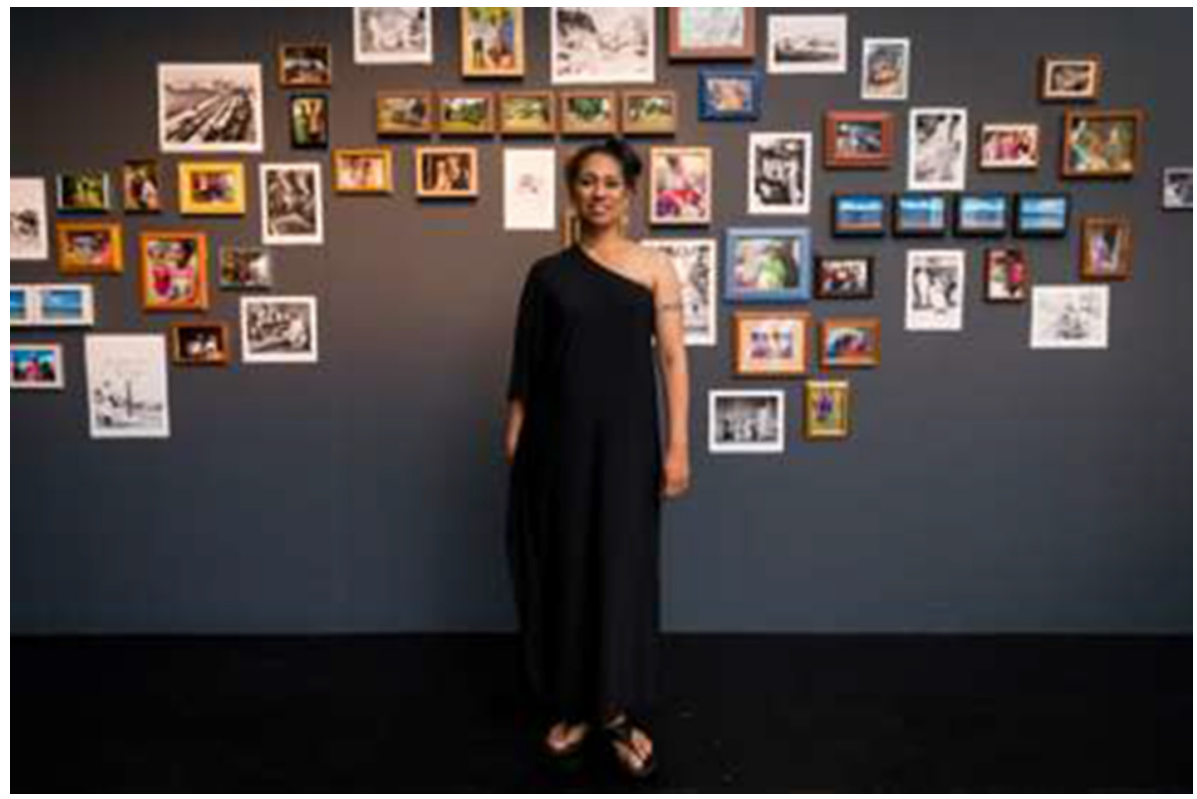

Figure 7 The artist and photo reef. From Project Banaba, Katerina Teaiwa, Carriageworks, Sydney. Image by Jacquie Manning. Used with permission 


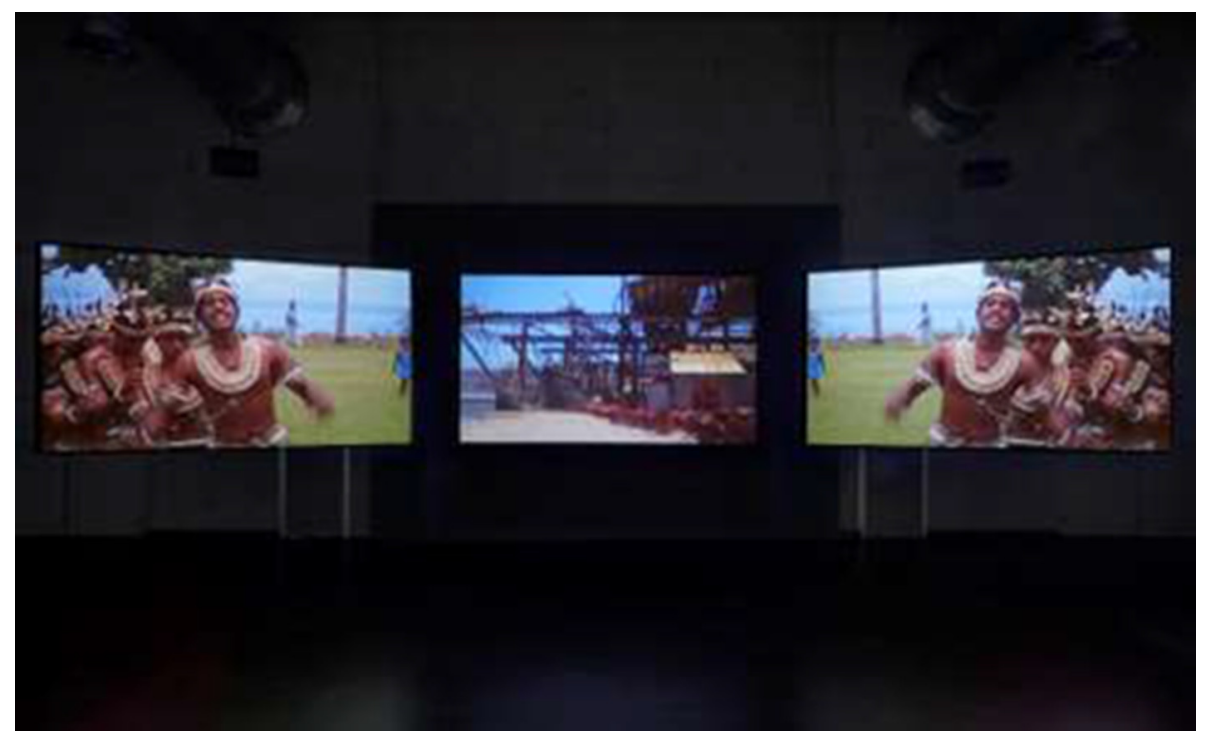

Figure 8 From Project Banaba, Katerina Teaiwa, MTG Tai Ahuriri, Hawke's Bay. Image by Katerina Teaiwa. Used with permission

mechanized. Screens drop in and out for emphasis. Soundtrack and editing combine to create tension at about the four-minute mark, as the theme phrase from Come and Get It returns to be repeated over and over, along with a stamping beat increasing its tempo. The central screen alone shows headlines depicting conflict. They include: 'BANABANS BOMB MINE - 8 HELD'; '55 BANABANS NOW FACE CHARGES'; 'OCEAN ISLAND “ARMED CAMP”,; 'THOUSANDS BACK BANABANS'; the headline an editor could not, unfortunately, resist, 'YES WE HAVE NO BANABANS', ending with 'FARMERS REAPED THE BENEFITS'. As well as the obvious point that agriculture elsewhere was the beneficiary of phosphate mining, several of these headlines refer to the period when Banabans returned to Banaba from Rabi and began agitating for both compensation and independence. One of the most moving sequences on the video is the sound of walking through the dry vegetation on current day Banaba, through wrecked buildings and rusting machinery. On the soundtrack, steps continue as the central screen continues to show abandoned building and rooms, while the two external screens show dancing and we hear singing on the new home of Rabi. Children cleverly make music with their mouths - 'a type of music called karebwerebwe by tapping their fingers against the side of their mouth ${ }^{177}$ - and play clapping games with song. Banaban life goes on, in part, on Rabi, though as the artist notes elsewhere, 'life expectancy is lower than in other parts of Fiji, health care is inadequate, the average age of marriage and start of childbearing is relatively young for women, and many Banaban and Gilbertese rituals have ceased to exist'. ${ }^{178}$ Just as the exhibition does, the video work finishes by becoming more personal, with footage of the artist as a younger

177. K Teaiwa (n 43), 192.

178. ibid, 195. 
woman travelling by boat to Banaba. ${ }^{179}$ On the soundtrack we hear her sister, the late Teresia Teaiwa, reading her poem 'For Salome':

A journey of a thousand miles begins beneath one's feet.

In the Earth.

Mother Earth, Father Sky.

Somewhere in the Pacific, they say that men have wings while women have only feet.

In other parts of the Pacific, they say women belong to the land while men belong to the sea.

Have you ever seen a woman stand on the beach and wail, wail at the sea and sky? ${ }^{180}$

The sounds of feet that have been heard stamping and walking the landscape come back into focus in this poem. Banaba is a long way from Rabi and cannot be reached on foot. The final shot following this poem is of a woman on the edge of the water with a small child. The camera pulls back to reveal broken machinery on the wharf before fading to black while the sound of the sea lapping the shore continues briefly. The exhibition is both a tale of devastation showing the very real loss of land and life on Banaba, and at the same time one of fierce survivance: ${ }^{181}$ the continuity and adaptation of vibrant cultural life into the present. Through the use of these multiple elements, the exhibition features a 'layering of material histories, relationships, and aesthetics. This nonlinear stylization capture[s] the sociocultural fragmentation, juxtaposition, and reclamation of identity and culture inherent in Banaba's history'. ${ }^{182}$

The Hawke's Bay iteration of the exhibition differed slightly in layout due to both gallery space and the decision to reflect the farming area surrounding the gallery. There is also an excerpt from another poem by Teresia Teaiwa, taken from 'In My Ideal Pacific':

In my ideal Pacific

my ancestral island of Banaba

or Ocean Island in the central

Pacific would not have been

mined into a moonscape oblivion

by the British Phosphate Company. ${ }^{183}$

This poem is displayed alongside an image of a New Zealand postage stamp celebrating the use of 'cropdusters', the small planes that released superphosphate over agricultural land to increase yields. The next verse of Teresia Teaiwa's poem, not seen in the exhibition, directly addresses the way in which New Zealand benefitted from the application of this fertilizer: 'New Zealand would not have/become quite such the land/of milk and honey that it did'. ${ }^{184}$ Though Project Banaba makes clear elsewhere

179. K Teaiwa, Personal communication, 2 March 2020.

180. K Teaiwa, Project Banaba; T Teaiwa, 'For Salome', in Teresia Teaiwa and Sia Figiel, Terenesia: Amplified Poetry and Songs ('Elepaio Press, Hawai 'i: Hawai 'i Dub Machine, 2000). 181. 'Survivance' is a term used by Gerald Vizenor to indicate continuity of Indigenous life despite the predations of colonization. Gerald Vizenor, Manifest Manners: Narratives on Postindian Survivance (University of Nebraska Press, Nebraska 1999).

182. Arbon (n 175), 238.

183. Katerina Teaiwa, Project Banaba, MTG Tai Ahuriri, Hawke's Bay, Aotearoa/New Zealand, March-September, 2019.

184. Pimpi Knows.com <https://pimpiknows.com/2017/03/21/in-my-ideal-pacific-teresiateaiwa/> accessed 27 February 2020. 
that the New Zealand Government was a co-owner, with Australia and the United Kingdom, of the phosphate company, the inclusion of this stamp by co-curator Jess Mio brings home the reality that, as direct beneficiaries, all New Zealanders are implicated in the devastation of Banaba.

\section{CLIMATE-INDUCED MIGRATION}

The story of the Banabans, especially of their apparently positive move to Rabi, has been hailed as a success by some scholars concerned with the fates of current and anticipated climate refugees in the region. Gil Marvel $\mathrm{P}$ Tabucanon, for example, is especially impressed by the ways in which later generations who had never lived on Banaba have maintained a distinct identity separate to that of the Fijians around them: 'the Banaban case demonstrates that not only is retention of collective identity possible among later generations but that ethnically distinct peoples need collective rights protection if they are to survive as a community'. ${ }^{185}$ Tabucanon goes on to suggest that, despite this, relative instability in Fiji not only threatens the Banaban community but that the legal protection of the 'distinct customs, traditions and histories' of any group forced to resettle due to climate change is still necessary. ${ }^{186}$ In a separate article, John Connell and Tabucanon compare the Rabi move with other 'less benevolent resettlements' where force of some kind was involved, such as the relocation of Bikini and neighbouring islanders due to nuclear testing, and relocations in Bougainville and Lihir in Papua New Guinea and Gold Ridge in the Solomon Islands due to mining. ${ }^{187}$ The authors claim that all of these moves involve 'the virtual impossibility of the migrants' return' ${ }^{188}$ yet while this is certainly true of several of these places, it ignores the population of around 400 Banabans and I-Kiribati living on Banaba today performing a role as caretakers and signalling the ongoing Banaban claim to this island, however devastated. ${ }^{189}$

In a survey of enforced relocation in the Pacific - and there are many instances Connell and Tabucanon conclude that 'Few of the circumstances that supported Rabi are likely to recur'. ${ }^{190}$ There are several specific circumstances that make the Banaban relocation unique rather than typical of what might be possible. These include the fact of the Banaban Fund, which, for all its problems, was an ongoing source of income and was drawn on for resettlement, and the availability of an island from which its original inhabitants had already been alienated. As a model, the Banaban relocation is unlikely to be emulated, relying so heavily as it does on these circumstances and on the ongoing generosity of the Fijians (though the original arrangement was a thoroughly colonial one made by the British). Banabans could therefore be considered to be lucky in the circumstances surrounding their relocation, but their sense of grief and of having been exploited lives on, and shows that the loss of homeland and sea - and the life made possible by them - remains terrible and deep.

185. Gil Marvel P Tabucanon, 'Continuity and Change: Identity and Rights Protection among Later Generation Banabans' (2014) 9(2) Shima: The International Journal of Research into Island Cultures 55-72, 55.

186. ibid.

187. Connell and Tabucanon (n 94), 92-3.

188. ibid, 93.

189. K Teaiwa (n 43), 5.

190. Connell and Tabucanon (n 94), 105. 


\subsection{Lessons for climate-induced migration}

In separate studies, Julia B Edwards and Jane McAdam identify specific lessons from the Banaban relocation that might be applied when rising sea levels and other climate catastrophes force other islanders to leave their ancestral homes. Citing instances of disquiet amongst both past refugees and the communities into which they have been relocated, McAdam concludes that consent is the key factor in making migration work: 'Widespread recognition now exists that relocation should only occur with the free and informed consent of the communities concerned'. ${ }^{191}$ This involves adequate information, and the possibility of contributing to the decision-making process, including the capacity to 'propose alternatives to relocation'. ${ }^{192}$ As well as agreeing on the importance of agency for those needing relocation - 'the involvement of the community at the initial discussion stage ${ }^{\prime 193}$ - Edwards notes two key elements that are necessary for establishing a community in a new location: 'long-term, postrelocation planning, including the creation of livelihoods, and on-going support by external agencies for those displaced'. ${ }^{194}$ This, however, was not the case with the Banabans. While their relocation had the appearance of occurring with the consent of the people, they had, in reality, few alternatives, and despite the Fund that enabled the purchase of the island, there were no occupations for people to take up when they arrived. Initially at least, beyond a couple of months' worth of supplies, subsistence was the only means of survival.

\section{CONCLUSION}

In whatever way climate-change-driven relocations might occur in the future, they will always involve loss. Where cultural identity is inherently bound up with a profound intimacy with land - in the Banaban case through land ownership - the lack of contact with that land is potentially debilitating: 'Being a Banaban entails having Ocean Island land, and having Ocean Island land is generally taken as presumptive evidence of being a Banaban'. ${ }^{195}$ For Banabans, this grief at the loss of ongoing interaction with the island of Banaba has been a binding, rather than dividing aspect of life on Rabi. Kempf and Hermann demonstrate how the memories of displacement and sense of grievance are kept alive in the Banaban community on Rabi through their culture, especially through dance; ${ }^{196}$ grief and memory are also being kept alive in the diaspora in Katerina Teaiwa's Project Banaba, which is making a new generation aware of this history. Similarly, the long struggles for compensation and legal recompense have unified the community with the sense of a shared goal in the face of a feeling of loss that is still very alive. For those that are living on Banaba, or who visit from Rabi, the devastation of the island is plain at every turn: 'On Banaba, where fishing grounds, homes, villages, and ritual and burial sites once existed, there are now stark limestone pinnacles, decaying processing plants, rusted

191. McAdam (n 89), 318.

192. ibid.

193. Edwards (n 109), 132.

194. ibid, 121.

195. Silverman (n 86), 185.

196. Kempf and Hermann (n 97), 374-83. 
storage bins, algae-congested water tanks, and a massive maritime cantilever with its giant arm crippled and submerged'. ${ }^{197}$

The dispersal of Banaban soil across the world offers new models for understanding the connections with land that form identity for Banabans. As Katerina Teaiwa conceptualizes it, 'Banaba is no longer a place, an island in the middle of an ocean, but rather a flow of rocks with multiple trajectories and itineraries. And if indigenous identities were or are rooted in specific landscapes and seascapes, then Banaban land and Banaban identities have now become coordinates between islands and continents'. ${ }^{198}$

Like their precious and sacred frigate bird, tamed for pleasure, fishing and ceremony, the Banaban people 'flew' to another island, but now live, like the bird of their imaginings, between islands: they are ocean peoples, who are now spread not only between Banaba and Rabi, but right across the globe through the remains of their ancestors.

197. K Teaiwa (n 43), 5 .

198. ibid, 11. 